\title{
Effect of Budgeting on Financial Perfomance of Youth Groups Funded by Youth Entreprise Fund in Kapsaret Sub-County, Kenya
}

\section{Kevin Otieno Owembi}

\author{
Kenya Institute of Management, Kenya.
}

\begin{abstract}
The study examined the effect of budgeting on financial performance of the Youth Groups at Kapsaret Sub-County. The study sought to answer the following questions; extent of budgeting by the youth groups at Kapsaret sub-county, factors affecting budgeting implementation and financial performance by the Youth Groups at Kapsaret Sub-county and budgeting effects on financial performance by the youth groups at Kapsaret Sub-county. The research design adopted for this study was Ex post-facto research design, the target population was the 82 youth groups being funded by the various financial institutions and YEDF in Kapsaret Sub-County Stratified sampling technique targeting youth groups managers and treasurers of the youth groups was used, 5 stratums were drawn from Kapsaret sub-county and data collected through simple random sampling technique. questionnaires administered to the target population was the source of primary data, Validity of questionnaires was tested using a pilot study on 6 Youth Groups out of the sampled groups and reliability was tested using the test-re-test method, descriptive statistic was used to analyze quantitative data presented through frequency tables, percentages, mean scores and standard deviation, chi-square was used to test the hypothesis. The study finding on the effect of standardized budgeting on financial performance using chi-square with the computed X2 value of 0.610 and the PValue of 0.435 ,the study established out that there was no evidence of a relationship between standardized budgeting and financial performance yet on the effect of budgeting on financial performance computed X2 value was 16.970 and the P-Value was 0.000 , the study established out that there was evidence of a relationship between budgeting and financial performance. The study recommends that there should be effective budget implementation within the various youth groups particularly those funded by the YEDF, more funding should be provided to the youth groups funded by YEDF, more training and seminars to be offered to the youth groups on preparation and implementation of budgets and there should be constant monitoring and evaluation of the youth groups budgets and budgeting system by fund managers over time within the youth groups.
\end{abstract}

Keywords: Budgeting, Financial Perfomance, Youth Entreprise.

\section{Introduction}

\section{Budgets}

It is a formal plan that estimates the probable expenditures and income by the various youth groups over a specific period of time.

\section{Budgeting}

Budgeting is the process of allocating finite resources to the prioritized needs of the youth groups over a specified period of time.

\section{Financial Performance}

Financial performance is a subjective measure, it's how well the youth groups can use its financial assets from its primary mode of business and generate revenues. It is also a general measure of the youth groups overall financial health over a given period of time.

\section{Measurement of Budgeting}

Budgeting was measured based on Formal Budget Planning which is the level of prediction of all expenditures, revenue, profits and returns, Budget Clarity which is the ability of these youth groups to come up with budgets which are clear and specific hence determining the easiness in their achievements, Budget Participation which is the process of joint decision making by two or more parties in influencing various elements of budgets and Budgetary Control which is a system within the youth groups in which actual income and spending are compared with planning income and spending so that the groups can see if the 
plans are being followed and if those plans need to be changed to make Profits.

\section{Measurement of Financial Performance}

Financial performance was measured based on profitability which is the ability of this youth groups to earn profit which is what is left from the revenue a business generates after it pays all expenses directly related to the generation of the revenue and Growth of funded projects which is the increase in the physical size and numbers of this youth funded projects.

\section{Description of the Study Area}

According to Independent Electoral and Boundary Kapsaret Sub-County is one of the progressive locations in Uasin-Gishu County in Kenya it is becoming a cosmopolitan region due to the numbers of town springing and growing up. Like many other areas in the country, the youth portions of the population in the age brackets of 15-30 years constitute the highest block of the area's population.

The provision of adequate and secure sources of gainful employment for youth as a way to mainstream them into community economic development is essential for the sub-county and hence, the country's economic growth and development. In Kenya and Kapsaret subcounty youth constitute the highest percentage of the population representing 65 $\%$ of the population.

\section{Statement of the Problem}

Despite the annual planning system by the government of Kenya every year and currently through the County governments, very little attention has been given to budgeting as a tool for achieving plan targets [1].To date various report from the YEDF has shown a staggering fund coupled with low repayment rate and the failure of the fund to meet its objectives [2].

Studies by Qi [3] on the effects of budgetary participation in the budgeting process on financial performance of Chinese SMEs found out that the extent of budgetary participation among Chinese SMEs affected to a large extend on their financial performance. A study by Kimando et al, [4] on Factors Affecting the Success of Youth Enterprise Funded Projects in Kenya at Kigumo subcounty Muranga County revealed the important need of budgeting for the youth groups as a measure by the government to enhance the financial success of this youth groups. However the effect is less clear with [5] finding that budgeting does not play a crucial role compared to increased capital and training as key factors for the success on SME's financial performance. None of the studies has examined so far the effectiveness of budgeting on financial performance at Kapsaret sub-county. Therefore this study investigated the effects of budgeting on financial performance of Youth Enterprise Funded groups in Kapsaret sub-county.

\section{Research Questions}

\section{The Study sort to Answer the Following Research Questions}

To what extent does youth groups at Kapsaret Sub-county budget for funds?

What are the factors affecting budgeting implementation and financial performance by the Youth Groups at Kapsaret Sub-county?

How does budgeting affects financial performance by the youth groups at Kapsaret Sub-county?

\section{Research Hypotheses}

The following Research Hypotheses Guided the Study

H1: There is a relationship between the Functionality of standardized budgeting and financial performance of the Youth Groups.

H2: There is no relationship between budgeting and financial performance of the Youth Groups.

\section{Literature Review}

Musando[6] recommended that awareness be created to the SMEs on the importance of the financial planning in business operations .Odera et al [7] recommended an increase in the number of financial intermediaries (FIs) in partnership with the fund and an active involvement of all the stakeholders in mobilization of the youth on group formation and YEDF activities Yet the study by [8] which established that the setting up of a cash balance policy ensures prudent cash budgeting and budgetary control system and investment of surplus cash. 
Found detailed need for budgetary controls where he found that Budgetary control integrates the organizations strategic planning with budgets and processes of cost control. found that operation costs for organizations could be reached through budgetary controls which in turn could have a positive implication on financial performance yet kung'u and mwangi [9] found out that there was a strong positive relationship between the fund management practices while a study by Kipkemboi [10] established that there was a weak positive relationship between budgetary control and performance of Non-Governmental Organizations in Kenya measured by $\mathrm{R}$ square at $14.3 \%$.

\section{Research Design and Methodology}

The design adopted for this study was ex postfacto research design. The research design employed was used be course it was not possible to conduct an experimental design on the study. The study aimed at obtaining the most recent and relevant information about how budgeting by the youth groups funded by YEDF had affected the financial performance of the youth groups in Kapsaret Sub-county in comparison to the other Youth Groups being funded by other financial institutions in Kapsaret Sub-County.

The Target population was the 82 youth groups in operation which are being funded by the various financial institutions and the Youth Enterprise Development Fund in Kapsaret Sub-County. The target experimental group for the study was the youth groups that had benefitted from Youth Enterprise Development Fund loan since its inception while the control group was the Youth Groups funded by other financial institutions in Kapsaret Sub-County.
A representative sample of 68 youth groups was required from the population this involved 68 group managers and 68 treasurers from this youth groups. The study used stratified sampling technique which involved drawing information from only the group managers and treasurers within the youth groups.

Since Kapsaret Sub-County has 5 SubConstituencies namely; Simat, Kipkenyo, Ngeria, Megun and Langas.5 strata's were formed and samples drawn out of each using simple random sampling as per the proportion of each computed population this involved distribution of questionnaires to 68 convenient groups within the 5 subconstituencies and 2 respondents consisting of group manager and a treasurer having to fill the questionnaire. The sample size was computed using the following simplified formula.

$$
\mathrm{n}=\frac{\mathrm{N}}{1+\mathrm{N}(\mathrm{e})^{2}}
$$

Confidence level is 95\% and Level of Precision being $5 \%$. Where $\mathrm{N}$ is the population and e is the level of precision. Proportional allocation was used to calculate various strata. The formula used is as follows: Where $\mathrm{n}=$ Population in a stratum $\mathrm{N}=$ Total number of Youth Groups.

$$
\begin{aligned}
& \mathrm{n}=\quad 82 \\
& 1+82\left(0 . \overline{05)^{2}}=68\right.
\end{aligned}
$$

A sample size of 68 resulted from the use of the above formula.

Table 1: Sample Size

\begin{tabular}{|c|c|c|}
\hline Sub-constituency & Population & Sample \\
\hline Simat & 20 & 17 \\
Kipkenyo & 12 & 10 \\
Ngeria & 16 & 13 \\
Megun & 14 & 11 \\
Langas & 20 & 17 \\
\hline Total & 82 & 68 \\
\hline
\end{tabular}


Data obtained from the questionnaires was coded, organized and analyzed through descriptive statistics and presented using frequency Tables, percentages, mean and standard deviation then hypothesis 1 and 2 tested using Chi-square at 0.05 level of significance. Presentation and Discussion of the Findings.

The study sought out to find out on the factors affecting budget implementation within the youth groups, this was of great importance considering the very fact that failure to budget by most organizations in the past have been blamed on Lack of knowledge on budget formulation this was also to understand if YEDF and the Financial Institutions are doing enough to sensitize the youth group members on budget formulation hence reducing this as a challenge.

In response to the question on the factors affecting budget implementation within the youth groups $56(100 \%)$ of the respondents from the groups funded by the YEDF indicated that inadequate training on budget implementation was to blame a major factor affecting budget implementation within the youth groups yet 50 (89\%) of the groups funded by the financial institutions indicated that inadequate training on budget formulation and implementation was the major factor affecting budget implementation within the youth groups while $6(11 \%)$ of the respondents indicated that Lack of knowledge on planning was the major factor affecting budget implementation within their youth groups, this shows that the fund managers both from the YEDF and the Financial Institutions have not done enough in training the various youth groups members on budget formulation and implementation.

In response to the question on Steps taken over the past years to improve on budget implementation within the youth groups. 10 (29\%) of the respondents from the groups funded by the YEDF indicated that the group was improving on individual budgeting to improve on budget implementation within the youth group while 25 (71\%) of the respondents indicated that the group had enhanced group participation to improve on budget implementation within the youth groups yet 19 (36 \%) of the groups funded by the financial institutions indicated that the group was improving on individual budgeting to improve on budget implementation within the youth group while $35(64 \%)$ of the respondents indicated that their group had enhanced group participation to improve on budget implementation within their youth groups. Low response from the group funded by the Youth Enterprise Development Fund might be an indicator that the groups were doing nothing to improve on budgeting which might be a worrying indicator as long as budgeting is concerned. In response to the question on how budgeting affects financial performance by the youth groups.

This research question was important as Objective performance indicators are necessary to monitor processes and measure change. This process of measuring financial performance often requires the use of statistical evidence to determine financial progress within the groups, comparison between the two groups in relationship to budgeting was then analyzed using the chisquare test, research questions asked to the respondents to answer the key research question involved; influence of budgeting on enhancing financial control within the groups, comparison of current and previous years revenue, comparison of current and previous years expenditure, whether revenue and expenditures are according to budget or financial plan, annual change in the number of project, extent of budgeting in improving financial performance, financial performance by the youth groups in 4 years' time, factors affecting budgeting and solution to this factors.

The study sought to determine if budgeting contributed positively to the financial control of the youth groups this was understood by respondents based on the ability of this youth groups to financial plan which are realistic and achievable by time though the use of the budgets.

There were five levels of relevance with regard to the Influence of Budgeting on enhancing financial control within the groups. Response was measured in a five level scale, to a very large extent which has been given 5 points, to a large extent which has been given 4 points, to a moderate extent which has been given 3 points, to some extent which has been given 3 points and to no extent which has been given 1 point. Mean and standard deviation were worked out for the analysis. 
Table 2: On influence of budgeting on enhancing financial control within the group

\begin{tabular}{|c|c|c|c|c|c|}
\hline Attribute & N & Min & Max & Mean & $\begin{array}{c}\text { Std. } \\
\text { Deviation }\end{array}$ \\
\hline Groups Funded by YEDF & 56 & 1 & 5 & 3.4 & 0.879 \\
\hline $\begin{array}{c}\text { Groups Funded by the Financial } \\
\text { Institutions }\end{array}$ & 56 & 1 & 5 & 3.9 & 0.645 \\
\hline
\end{tabular}

On Influence of Budgeting on enhancing financial control within the group respondents from the youth groups funded by the YEDF indicated that budgeting played to a moderate extent (mean 3.4) on enhancing financial performance of the youth groups with a deviation of 0.879. This shows that majority of the respondents were not sure on the influence of budgeting to financial performance which would be expected considering the fact that most of the groups funded by the YEDF did not have a budget.

To the groups funded by the financial Institutions It was found that budgeting played to a large extent (mean 3.9) on enhancing financial control within the groups with a deviation from the mean of 0.645 which meant that over time budgeting have helped the group have control over their revenue and expenditure. The study sought to determine on the extent of budgeting on helping the youth groups improve the level of financial performance, this was understood by respondents based on the ability of budgeting to help the groups improve on their financial performance which was measured in terms of increased profit and changes in the number of projects. There were five levels of relevance with regard to the extent of budgeting on helping the youth groups assess the level of financial performance.

Response was measured in a five level scale, to a very large extent which has been given 5 points, to a large great extent which has been given 4 points, to a moderate extent which has been given 3 points, to some extent which has been given 3 points and to no extent which has been given 1 point. Mean and standard deviation were worked out for the analysis.

Table 3: On the extent of budgeting on helping the youth groups improve on financial performance

\begin{tabular}{|c|c|c|c|c|c|}
\hline Attribute & N & Min & Max & Mean & Std. Deviation \\
\hline Groups Funded by YEDF & 56 & 1 & 5 & 2.6 & 0.845 \\
\hline $\begin{array}{c}\text { Groups Funded by the Financial } \\
\text { Institutions }\end{array}$ & 56 & 1 & 5 & 4.4 & 0.679 \\
\hline Average & & & & 3.5 & 0.762 \\
\hline
\end{tabular}

On the extent to which budgeting helps youth groups improve on financial performance the study found out that the average extent of budgets on improving financial performance was to a large extent (Mean 3.5) with a deviation of 0.762 .

This shows that though budgets was not fully embraced by all of the groups still it played a very big role in helping those groups having budgets achieve good financial performance which is justified by the mean of (4.4)of the groups funded by the financial institutions which have budgets and to those without budgets they still felt that with the introduction of budgeting within their youth groups then their financial performance could improve with a large extent. On factors affecting budgeting by various youth groups the respondents indicated that budgeting process is affected by ever-increasing cost of production, 3(6\%) of the respondents indicated that wastage by group members was a major factor affected budgeting, 7(14\%) respondents indicated that high interest rate was a major factor affecting budgeting within the youth groups, $12(24 \%)$ of the respondents indicated that inflation was a key factor yet $17(34 \%)$ of the respondents indicated that limited knowledge about the budget was a major factor yet $6(13 \%)$ of the respondents indicated that unexpected expenditure about budgeting was a major factor affecting their budgeting process within their youth groups.

On solutions to the factors affecting budgeting by the youth groups $3(6 \%)$ of the respondents indicated that Increase on supervision by the fund managers was a solutions to the factors affecting budgeting within the youth 
groups, 17 (34\%) of respondents indicated that training and offering of more seminars to the youth group members on fund utilization was a major solution to factors affecting budgeting within the youth groups yet $25(48 \%)$ of the respondents indicating that introduction of budgeting system was a major solution to the factors affecting budgeting within the youth groups.

\section{Test of Hypothesis}

Chi-Square testing the relationship between standardized budgeting and financial performance of the Youth Groups.

The following null hypothesis was tested using chi-square at 0.05 level of significance

Ho1: There is no significant relationship between standardized budgeting and financial performance of the Youth Groups.

Table 4: Chi-Square result on the relationship between standardized budgeting and financial performance

\begin{tabular}{|c|c|c|c|c|c|}
\hline \multicolumn{6}{|c|}{ Chi-Square Tests } \\
\hline & Value & df & $\begin{array}{c}\text { Asymp. Sig. (2- } \\
\text { sided) }\end{array}$ & $\begin{array}{l}\text { Exact Sig. (2- } \\
\text { sided) }\end{array}$ & $\begin{array}{c}\text { Exact Sig. (1- } \\
\text { sided) }\end{array}$ \\
\hline P earson Chi-Square & $.610^{\mathrm{a}}$ & 1 & .435 & & \\
\hline Continuity Correction ${ }^{b}$ & .000 & 1 & 1.000 & & \\
\hline Likelihood Ratio & 1.106 & 1 & 293 & & \\
\hline Fisher's Exact Test & & & & 1.000 & .578 \\
\hline inear-by-Linear Association & .600 & 1 & 439 & & \\
\hline $\mathrm{N}$ of Valid Cases & 64 & & & & \\
\hline \multicolumn{6}{|c|}{ a. 2 cells $(50.0 \%)$ have expected count less than 5 . The minimum expected count is .50 . } \\
\hline & & & & & \\
\hline
\end{tabular}

Computed chi-square value is 0.610 and the $\mathrm{P}$-value is 0.435 . Since the $\mathrm{p}$-value is greater than 0.05 (level of significance) the null hypotheses is not rejected and the study therefore concludes that there is no evidence of a relationship between standardized budgeting and financial performance. This suggests that the level of financial performance of this youth groups will not be affected whether the youth groups follow or do not follow budgeting standards which have been set by international bodies.
Chi-Square testing the relationship between budgeting and financial performance of the Youth Groups

The following null hypothesis was tested using chi-square at 0.05 level of significance

Ho1: There is no significant relationship between budgeting and financial performance of the Youth Groups.

Table 5: Chi-Square result on the relationship between budgeting and financial performance

\begin{tabular}{|c|c|c|c|c|c|}
\hline 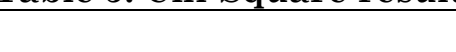 & & hi-S & re Tests & & \\
\hline & Value & $\mathrm{df}$ & $\begin{array}{c}\text { Asymp. Sig. (2- } \\
\text { sided) }\end{array}$ & $\begin{array}{l}\text { Exact Sig. (2- } \\
\text { sided) }\end{array}$ & $\begin{array}{l}\text { Exact Sig. (1- } \\
\text { sided) }\end{array}$ \\
\hline Pearson Chi-Square & $16.970^{\mathrm{a}}$ & 1 & .000 & & \\
\hline Continuity Correction ${ }^{b}$ & 15.048 & 1 & .000 & & \\
\hline Likelihood Ratio & 17.537 & 1 & .000 & & \\
\hline Fisher's Exact Test & & & & .000 & .000 \\
\hline inear-by-Linear Association & 16.818 & 1 & .000 & & \\
\hline $\mathrm{N}$ of Valid Cases & 112 & & & & \\
\hline a. 0 cells $(0.0 \%)$ hav & cte & & 5. The minin & cte & s 9.43. \\
\hline
\end{tabular}

Computed chi-square value is 16.970 and the $\mathrm{P}$-value is 0.000. Since the $\mathrm{p}$-value is lower than 0.05 (level of significance) the null hypotheses is rejected and the study therefore concludes that there is an evidence of a relationship between budgeting and financial performance. This suggests that budgeting plays a vital role in the financial performance of the various youth groups and it should be accepted by those groups that are not budgeting for their funds. 


\section{Conclusion}

On relationship between budgeting and financial performance of the Youth Groups, computed X2 value is 16.970 and the $\mathrm{P}$ Value is 0.000 . This shows that there is an evidence of a relationship between budgeting and financial performance which suggests that budgeting plays a vital role in the financial performance of the various youth groups and if introduced to all youth groups then with other factors held constant there financial performance will improve.

When implementing the budget within the individual youth groups, budget decision makers should involve fund managers and other stakeholders through periodic communication and incase of any deviation from the initial financial plan then the fund managers in coordination with the group leaders should investigate this seriously considering the external changes that have occurred in the budget during the period.

\section{Recommendations}

Based on the findings and conclusions of the study, the following recommendations were made; Effective budget implementation within the various youth groups particularly those funded by the Youth Enterprise Development Fund should be facilitated through capacity building on these groups. There should be more seminars to the youth groups on preparation and implementation of budgets with a very clear emphasis on the entire financial systems and processes within the youth groups with a constant monitoring and evaluation of the budgets and budgeting system of this youth groups by the fund managers over time.

There should be more training to the fund managers within the Youth Enterprise Development Fund on budgets and effective budgeting process which should be of gain to the youth groups by individual youth group having an active extra member from the Youth Fund to support the group on budget development and budgeting process this will reduce deviation from achieving budget target and enhancing continuous participation between Youth Enterprise Development Fund and the individual groups. From the finding of the study it's clear that the youth groups funded by the YEDF are not receiving adequate funds to finance their projects and this has affected to a large extend the ability of this youth groups to plan adequately for their projects hence this youth groups should be funded adequately with an understanding of the financial objectives of the individual group.

There is need for adequate sensitization of both the youth group leaders and fund managers within the Youth Enterprise Development Fund to clearly understand the objective of the fund on improving the financial stability of the Kenyan Youths in the long run plus stability of the fund in the long run and on best financial management practices so that the fund does not lose its objective and become a thing of the past in a few years to come as projected from the study [11-14].

\section{References}

1. Kiringai JA (2002) Budget Reforms and Medium term expenditure framework in Kenya KIPPRA, working, Nairobi, Nairobi: Kenya Institute for Public policy, Research and Analysis.

2. Barasa KM, Githae PP (2015) 'The Effect of Lending Conditions on Accessibility of Funds for Youth Entrepreneurs in Matungu Constituency, Kakamega County, Kenya', European Journal of Business and Social Sciences 4 (6):30-9.

3. Yang Qi (2010) the impact of the budgeting process on performance in small and medium sized firms in china.PHD Thesis, University of Twenth. 23-50.

4. Kimando LN, Njogu GW, Kihoro JM (2012) Factors Affecting the Success of Youth Enterprise Development Funded Projects in Kenya; A Survey of Kigumo District Muranga County. International Journal of Business and Commerce, 1(10):61-81.

5. Oywa KO (2012) Factors influencing performance of youth group micro and small enterprises in kisumu west district, Kisumu County. MBA Thesis. kenyatta University.

6. Musando JA (2013) the relationship between financial planning and the

financial performance of small and medium enterprises in Nairobi city centre Kenya. MBA Thesis. University of Nairobi.

7. Okoth OS, Okelo S, Aila1 F, Awiti OA, Onyango M, Ogutu M, Odera O (2013) 
Effect of the Youth Enterprise Development Fund on Youth Enterprises in Kenya. International Journal of Advances in Management and Economics, 2 (1):11111.

8. Kwame K (2007) Working capital management practices of SMES in the ashauti region. Ghana. Retrieved from http://www.ssm.com on January 2010

9. Kung'u N, Mwangi K (2014) Effects of Fund Management Practices on Financial Performance in CDF funded Water Projects in Kenya. IOSR Journal of Economics and Finance, 2321-5925. 5 (3):53-60.

10.Kipkemboi SS (2011) effect of budgetary control on performance of nongovernmental organizations in Kenya.MBA Thesis. University of Nairobi.
11. Atrill P (2006) financial management for decision makers 4th edition, London, Prentice Hall.

12.Government of Kenya (2006) Micro and Small Enterprises Bill. Nairobi: Government printer.

13.Government of Kenya (2005) Sessional Paper number 2 of 2005 on development of SMEs for wealth and employment creation. Nairobi: Government printer.

14.Oduol S. et al (2013) Effect of Youth Enterprise Development Fund on youth enterprises in Kenya. International Journal of Advances in Management and Economics, 2 (1):1112-116. 